\title{
Cardiac MRI: Diagnostic Gain of an Additional Axial SSFP Chest Sequence for the Detection of Potentially Significant Extracardiac Findings in the Cardiac MRI Examination Setting
}

\section{Diagnostischer Nutzen einer zusätzlichen axialen true-FISP Sequenz in der kardialen MRT-Untersuchung für die Detektion potentiell signifikanter extrakardialer Befunde?}

Authors

Affiliations
F. C. Roller ${ }^{1}$, C. Schneider ${ }^{1}$, A. Schuhbäck ${ }^{2}$, A. Rolf ${ }^{3}$, G. A. Krombach ${ }^{1}$

1 University Hospital Giessen, Department Radiology

2 University Hospital Giessen, Department Cardiology

Kerckhoff Hospital Bad Nauheim, Department Cardiology
Key words

- cardiac

- MR imaging

- MR angiography

received $\quad 9.9 .2012$

accepted 25.6.2013

Bibliography

Dol http://dx.doi.org/

10.1055/s-0033-1350193

Published online: 24.7.2013

Fortschr Röntgenstr 2014; 186: 42-46 @ Georg Thieme Verlag KG Stuttgart · New York . ISSN 1438-9029

\section{Correspondence}

Herr Dr. Fritz Christian Roller

Radiologie, Universitätsklinikum Giessen

Klinikstraße 36

35392 Giessen

Germany

Tel.: ++ 49/06 41/98556329

Fax: ++49/06 41/98541809

fritz.c.roller@radiol.med.uni-

giessen.de

\section{Zusammenfassung}

$\nabla$

Ziel: Die kardiale Magnetresonanztomografie (MRT) stellt eine sehr effektive Untersuchungsmethode des Herzens dar. Ziel unserer Studie war es zu untersuchen, ob sich die Integration einer zusätzlichen axialen Thoraxsequenz in der MRT-Untersuchung des Herzens vorteilhaft in Bezug auf die Detektion potentiell signifikanter extrakardialer Befunde auswirkt.

Material und Methoden: Insgesamt wurden 400 aufeinanderfolgende MRT-Untersuchungen des Herzens ausgewertet. Bei diesen Untersuchungen wurde zusätzlich zu den standardisierten kurzachsen und langachsen Sequenzen eine axiale SSFP Sequenz hinzugefügt, die den Thorax von der Lungenspitze bis zum Diaphragma abbildet. Es erfolgte eine separate Auswertung der Sequenzen hinsichtlich potentiell signifikanter extrakardialer Befunde.

Ergebnisse: Insgesamt wurden 25 potentiell signifikante extrakardiale Befunde in den 400 Patienten diagnostiziert. Hierunter waren 16 Pleuraergüsse mit unterschiedlichen Ausmaßen, eine Lungenfibrose, eine Spondylodiszitis, Aszites, mediastinale Lymphadenopathie, ein Mammakarzinomrezidiv mit Metastasen im Mediastinum, das Wachstum von Nebennierenmetastasen und unklarer Zwerchfellhochstand. Alle 25 potentiell signifikanten Nebenbefunde konnten in den SurveySequenzen detektiert werden. 24 der 25 potentiell signifikanten Nebenbefunde konnten in der zusätzlichen axialen Thoraxsequenz (SSFP) detektiert werden.

Schlussfolgerung: Unsere Studie zeigt, dass die Einführung einer axialen SSFP Sequenz zusätzlich zu den kardialen Standardsequenzen keine Mehrnutzen bei der Detektion potentiell signifikanter extrakardialer Befunde hat. Mit Hilfe der SurveySequenzen war es möglich alle potentiell signifikanten extrakardialen Nebenbefunde zu detektieren. Somit kommen wir zu dem Schluss, dass die

\section{Abstract \\ $\nabla$}

Purpose: Cardiac MRI (CMRI) is an effective method for imaging of the heart. The aim of our study was to assess whether an axial chest sequence in addition to the standard CMR examination setting has advantages in the detection of potentially significant extracardiac findings (PSEF).

Materials and Methods: 400 consecutive patients were imaged at $1.5 \mathrm{~T}$ for clinical reasons. In addition to the standard long and short-axis views, an axial SSFP sequence was obtained covering the thorax from the lung apex to the diaphragm. All sequences were separately evaluated for PSEF. Results: A total of 25 PSEF were diagnosed in 400 patients, including 16 pleural effusions, a pulmonary fibrosis, a spondylodiscitis, ascites, lymphadenopathies, relapse of a mamma carcinoma, growth of adrenal glands metastases and diaphragmatic elevation. All 25 PSEF were detected by reading survey sequences. 24 of the 25 PSEF were detected by the additional SSFP chest sequence as well as the CINE sequences.

Conclusion: In our study the additional axial SSFP chest sequence didn't show a benefit in the detection of PSEF. With the survey sequences we were able to detect all PSEF. We conclude that survey images should be assessed for additional findings. Citation Format:

- Roller FC, Schneider C, Schuhbäck A et al. Cardiac MRI: Diagnostic Gain of an Additional Axial SSFP Chest Sequence for the Detection of Potentially Significant Extracardiac Findings in the Cardiac MRI Examination Setting. Fortschr Röntgenstr 2014; 186: 42-46 
Survey-Sequenzen in der kardialen MRT-Untersuchung gründlich hinsichtlich extrakardialer Nebenbefunde betrachtet werden sollten.

\section{Introduction}

\section{$\nabla$}

Cardiac MRI (CMRI) is a noninvasive and effective method for imaging the heart and provides excellent visualization of cardiac structure and quantification of heart function. The imaging problems of the past due to cardiac motion were widely resolved by designing new sequences and increasing the imaging speeds at the beginning of this century. In the last decade CMRI has become a powerful diagnostic tool and now plays a significant role in the diagnosis of myocardial infarction, coronary artery diseases, congenital heart disease, non-ischemic cardiomyopathies, heart insufficiency, inflammation of the heart, infiltrative disorders, valvular diseases and heart tumors. To predict the suitability of CMRI and cardiac computed tomography (CT) for different issues and clinical scenarios, a German consensus document was developed in collaboration by the German Cardiac Society, the German Radiology Society and the German Society of Pediatric Cardiology [1]. For this purpose a 5-point scale was designed to rate the indication level for the use of CMRI and cardiac CT.

Beside the evaluation of the heart, additional imaging information is generated in the CMRI examination setting. Delineation of partly and totally included thoracic and abdominal structures with incidental detection of non-cardiac pathology is obtained. Potentially significant extracardiac findings (PSEF) and non-significant extracardiac findings can be distinguished. PSEF are defined as potentially important additional findings which perhaps require further evaluation with additional imaging or la- boratory tests, tissue sampling, further clinical assessment or possibly therapeutic intervention in the patient management [2]. The prevalence of incidental findings in other cross-sectional imaging methods, for example CT-colonography [3 - 5] and cardiac CT, is already well described [6-12]. A newer study also assessed the prevalence of incidental findings in CT of the lumbar spine [13]. CMRI studies are less thoroughly investigated and only a few studies deal with the prevalence of potentially significant and non-significant extracardiac findings. In these studies extracardiac findings are reported with a wide range between $7.6 \%$ and $81 \%$ with a prevalence of potentially significant extracardiac findings between $3.1 \%$ and $21 \%$ [ $14-16]$. In addition to these prevalence rates, the study of Wyttenbach et al. compared the intraobserver variability between the original clinical reading and the second dedicated reading of the CMR study. Wyttenbach et al. showed a significantly higher detection rate of secondary findings in the secondary image reading [16].

At our institution an additional axial SSFP (steady state free precession) chest sequence is implemented in the CMRI setting. This SSFP chest sequence covers the thorax from the lung apex to the diaphragm and requires an acquisition time of 20 to 30 seconds ( $\bullet$ Fig. 1). The reason for obtaining this sequence is to generate an overview of cardiac anatomy and to evaluate the thorax for additional findings.

The aim of our study was to systematically analyze the diagnostic gain of the additional axial SSFP sequence for the detection of PSEF.
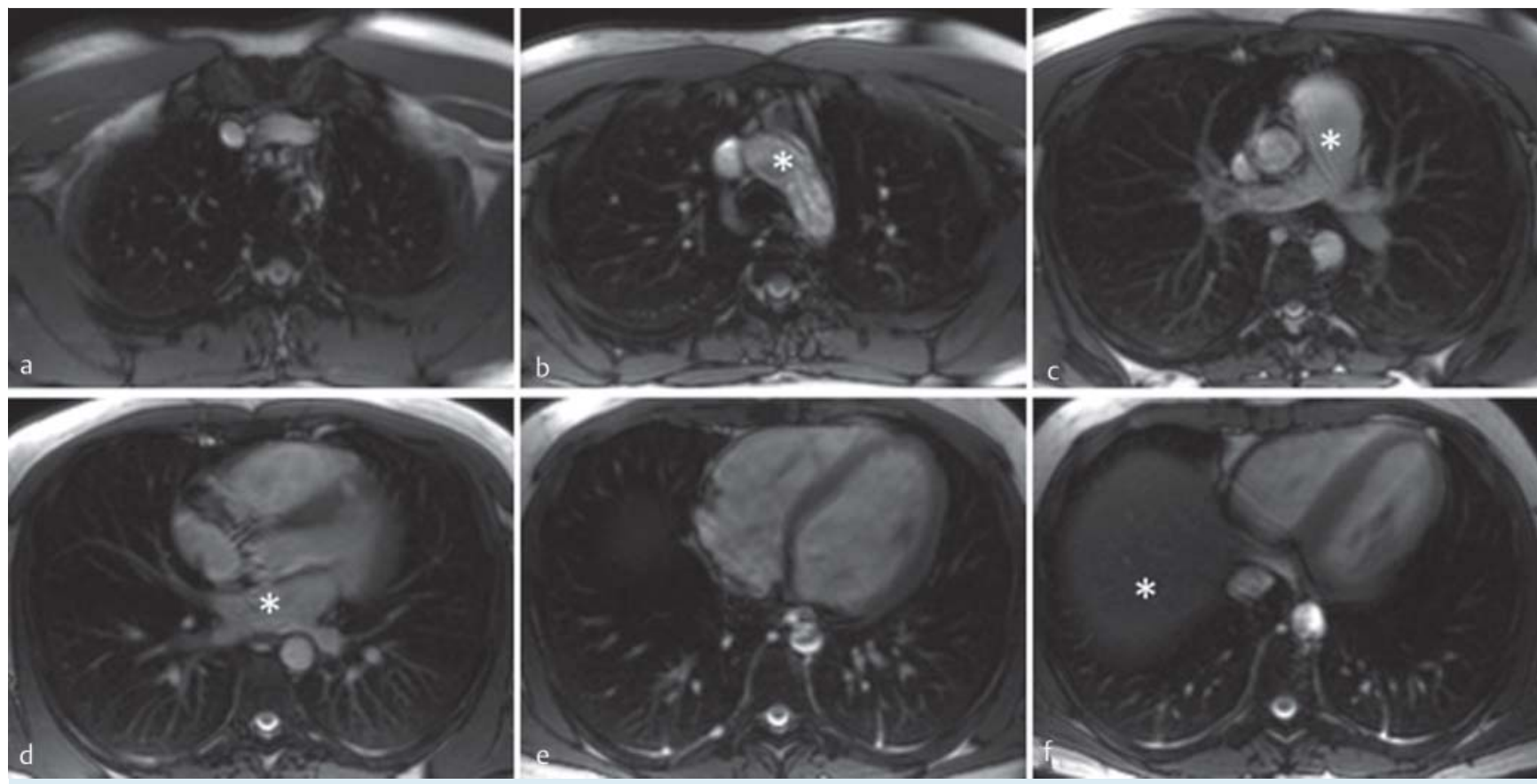

Fig. 1 The figure shows examples of the additional axial SSFP chest sequence at different heights in a healthy patient. a Apex of the lung b Aortic arch (white star) c Pulmonary trunk (white star) d Central lung veins (white star) e Two-chamber view of the heart $\mathbf{f}$ Including the diaphragm of the right side (white star)

Abb. 1 Die Abbildung zeigt Beispielbilder der axialen thorakalen SSFP Sequenz auf unterschiedlichen Höhen des Thorax in einem Normalbefund. a Lungenspitzenfeld b Aortenbogen (weißer Stern) c Truncus pulmonalis (weißer Stern) d Zentrale Lungenvenen (weißer Stern) e Zwei Kammer Blick des Herzens f Auf Höhe des rechten Zwerchfellschenkels (weißer Stern) 


\section{Materials and Methods}

$\nabla$

Imaging was performed with a Siemens Avanto 1.5 Tesla scanner and a Philips Intera 1.5 Tesla scanner using a dedicated cardiac coil. Standardized CMR examination protocols based on the clinical indications containing axial, coronal and sagittal thoracic survey images, balanced fast field echo sequences, SSFP sequences, black-blood sequences, late gadolinium enhancement sequences (LGE) and, when indicated clinically, myocardial perfusion sequences with intravenous adenosine infusion were used. In addition to the standard sequences, an axial SSFP sequence covering the thorax from the lung apex to the diaphragm with a slice thickness of $6 \mathrm{~mm}$ or $8 \mathrm{~mm}$ depending on the MRI scanner being used was obtained. The imaging parameters were: TR $285.16 \mathrm{~ms}$, TE $1.14 \mathrm{~ms}$, FoV 400x400, matrix 256x168 and $7.2 \mathrm{~mm}$ gap.

400 consecutive investigations were analyzed. All patients were imaged between April 2010 and September 2011. 223 males and 177 females were included in the current study. The mean age was 52 years $(+/-18$ years standard deviation) with a range between 17 and 88 years. The most common indications for CMRI were ischemic heart diseases in 149 patients (37.25\%) and

Table 1 CMRI indications.

Tab. 1 Indikationen für die Kardio-MRT Untersuchungen.

\begin{tabular}{|c|c|c|}
\hline & total (n) & percent (\%) \\
\hline ischemic heart disease & 149 & 37.25 \\
\hline $\begin{array}{l}\text { cardiomyopathy, myocarditis and } \\
\text { arrhythmia }\end{array}$ & 162 & 40.5 \\
\hline congenital heart disease & 18 & 4.5 \\
\hline Sarcoidosis & 11 & 2.75 \\
\hline transposition of pulmonary veins & 9 & 2.25 \\
\hline fabry disease & 7 & 1.75 \\
\hline aortic aneurysm & 7 & 1.75 \\
\hline thrombus & 5 & 1.25 \\
\hline others (tumors) & 22 & 5.5 \\
\hline
\end{tabular}

an aggregation of indications including cardiomyopathy, myocarditis and evaluation prior to implantation of implantable cardiac defibrillator (ICD) in 162 patients (40.5\%). The indications for the CMR studies are summarized in 0 Table 1.

The axial SSFP images, the survey images covering the thorax from the lung apex to the upper abdomen (SSFP, TR $323.84 \mathrm{~ms}$, TE $1.14 \mathrm{~ms}$, FoV 352x356, matrix 272x170, slice thickness $8 \mathrm{~mm}$ and $32 \mathrm{~mm}$ gap) and the sequences tailored to imaging of the heart were evaluated in consensus for the presence of PSEF by two experienced readers. In addition, the age of all patients with PSEF was evaluated and the patients were summarized in age groups.

\section{Results \\ $\nabla$}

A total of 25 PSEF were diagnosed including 16 pleural effusions with greater or lesser degrees of dystelectasis, an amiodarone-induced pulmonary fibrosis ( $\bullet$ Fig. 2a, b), a relapse of a mamma carcinoma with a mass in the upper mediastinum ( $\bullet$ Fig. 2c, d), a spondylodiscitis ( $\bullet$ Fig. 3), a lymphadenopathy at the hilum, a lymphadenopathy of the mediastinum, growth of adrenal gland

Table 2 Summary of potentially significant extracardiac findings (PSEF).

Tab. 2 Zusammenfassung der potentiell signifikanten extrakardialen Befunde.

\begin{tabular}{|l|l|}
\hline & total (n) \\
\hline pleural effusion with dystelectasis & 16 \\
\hline pulmonary fibrosis & 1 \\
\hline spondylodiscitis & 1 \\
\hline adrenal glands metastases & 1 \\
\hline relapse of mamma carcinoma & 1 \\
\hline hilary lymphadenopathy & 1 \\
\hline mediastinal lymphadenopathy & 1 \\
\hline liver cirrhosis with ascites & 1 \\
\hline diaphragmatic elevation & 2 \\
\hline
\end{tabular}
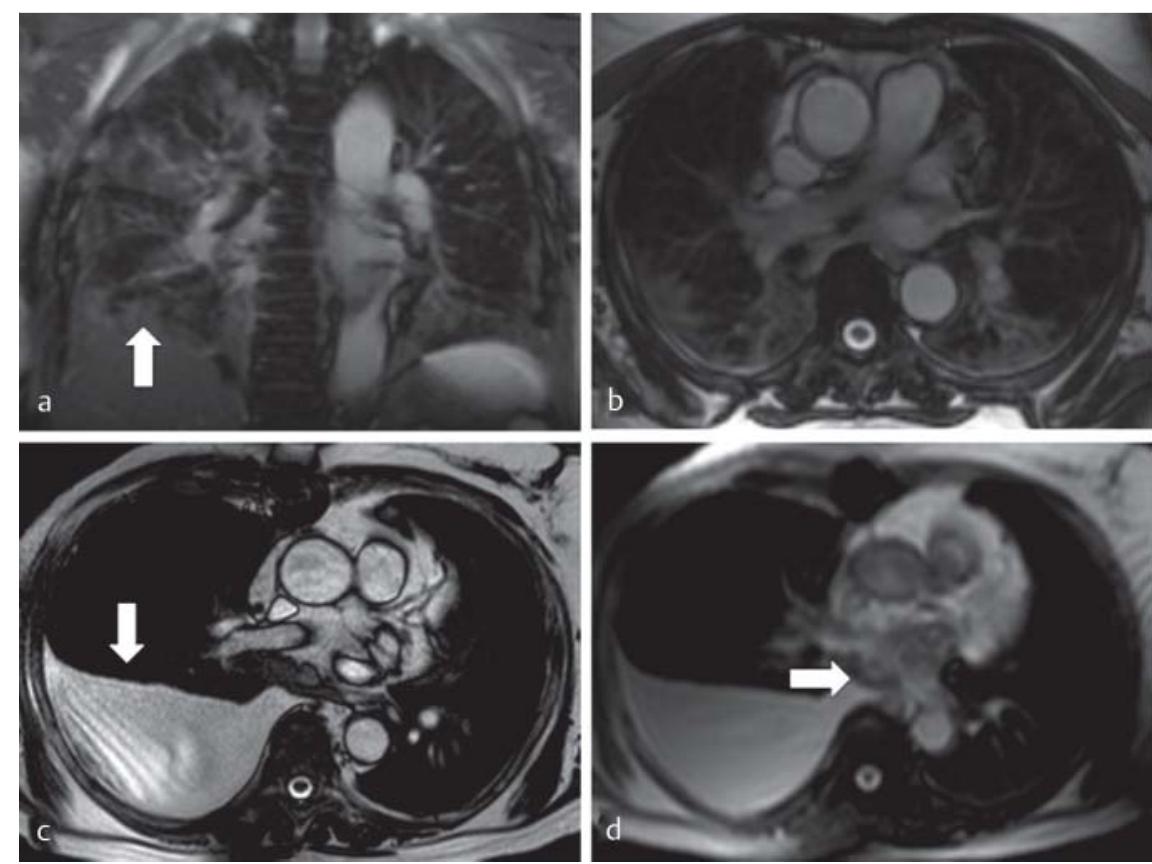

Fig. 2 Amiodarone-induced pulmonary fibrosis with thickening of the interlobular septa (white arrow) and indicated honeycombing are shown in a coronary survey sequence $\mathbf{a}$ and in the axial SSFP chest sequence $\mathbf{b}$. Pleural effusion (white arrow) on the right side and a mediastinal mass (white star) in the case of a mamma carcinoma relapse are shown in an axial survey sequence $\mathbf{c}$ and in the axial SSFP chest sequence $\mathbf{d}$.

Abb.2 Die Abbildungen a, $\mathbf{b}$ zeigen die Amiodaron induzierte Lungenfibrose mit Verdickung des interlobulären Bindegewebes (weißer Pfeil) und angedeutete Wabenbildungen im Survey a und in der axialen SSFP Sequenz $\mathbf{b}$. Die Abbildungen $\mathbf{c}, \mathbf{d}$ zeigen eine Pleuraerguss (weißer Pfeil) und mediastinale Metastasen (weißer Stern) in einem Fall eines Mammakarzinom Rezidives im Survey $\mathbf{c}$ und in der axialen SSFP Sequenz $\mathbf{d}$. 
metastasis in a case of renal cancer ( $\bullet$ Fig. $4 a, b$ ), ascites in a patient with liver cirrhosis ( $\bullet$ Fig. 4c, d) and two cases of diaphragmatic elevation. The PSEF are summarized in $\bullet$ Table 2.

A total of 16 PSEF (61.5\%) including the relapse of the mamma carcinoma, the growth of the adrenal gland metastasis, the spondylodiscitis and the amiodarone-induced pulmonary fibrosis were not known previously. In these 4 cases further additional imaging was required. In the case of the mamma carcinoma relapse, CT and PET (positron emission tomography)-CT were required, in the case of the adrenal gland metastases, CT was also
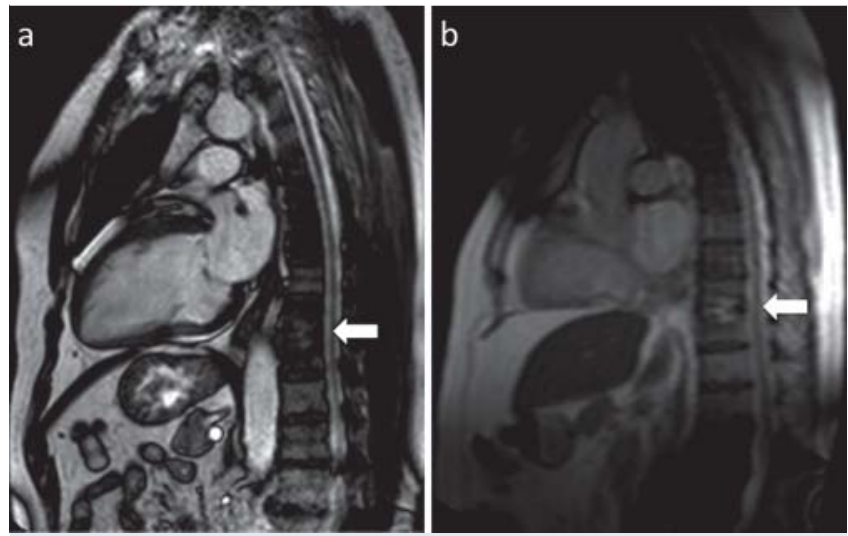

Fig. 3 The images show the spondylodiscitis (white arrows) with irregular signal intensity in the lesser thoracic spine - hypointense in the sagittal survey sequence $\mathbf{a}$ and hyperintense in the cardiac examination sequence $\mathbf{b}$.

Abb. 3 Die Abbildung zeigt eine Spondylodiszitis (weiße Pfeile) in der unteren Brustwirbelsäule mit einem irregulären Signalmuster in der sagittalen Survey Sequenz mit hypointensem Signal a und in einer kardialen Untersuchungssequenz mit hyperintensem Signal b. required for further diagnostic measures, the spondylodiscitis required MRI, and the pulmonary fibrosis required HRCT (high-resolution computed tomography). 24 of the 25 PSEF were visible on the additional axial SSFP chest sequence and all PSEF were visible in the survey sequences. The adrenal gland metastases were not visualized in the cardiac examination sequences and in the additional SSFP chest sequence. This pathology was only delineated in the survey sequences. Table 3 shows the PSEF in relation to the cardiac MRI sequences in which they were visible. $64 \%$ of the PSEF were detected in the patient group older than 50 years and $78 \%$ were detected in the patient group older than 40 years. $\odot$ Table 4 shows the relationship between PSEF and patient age.

\section{Discussion \\ $\nabla$}

With $6.25 \%$ PSEF our study showed a comparable prevalence to previously published results [14-16]. A total of 16 PSEF (61.5\%) were not known previously. In 4 cases further imaging including HRCT, PET-CT, MRI and CT was required.

The implemented additional axial SSFP chest sequence in the CMRI setting poses an additional time loss of $20-30$ seconds

Table 3 PSEF according to detecting sequences.

Tab. 3 Visualisierbarkeit potentiell signifikanter extrakardialer Befunde aufgegliedert nach kardialen MRT Sequenzen.

\begin{tabular}{|lll|}
\hline & total (n) & percent (\%) \\
\hline survey sequence & 25 & 100 \\
\hline functional heart sequences & 24 & 96 \\
\hline true-FISP sequence & 24 & 96 \\
\hline
\end{tabular}
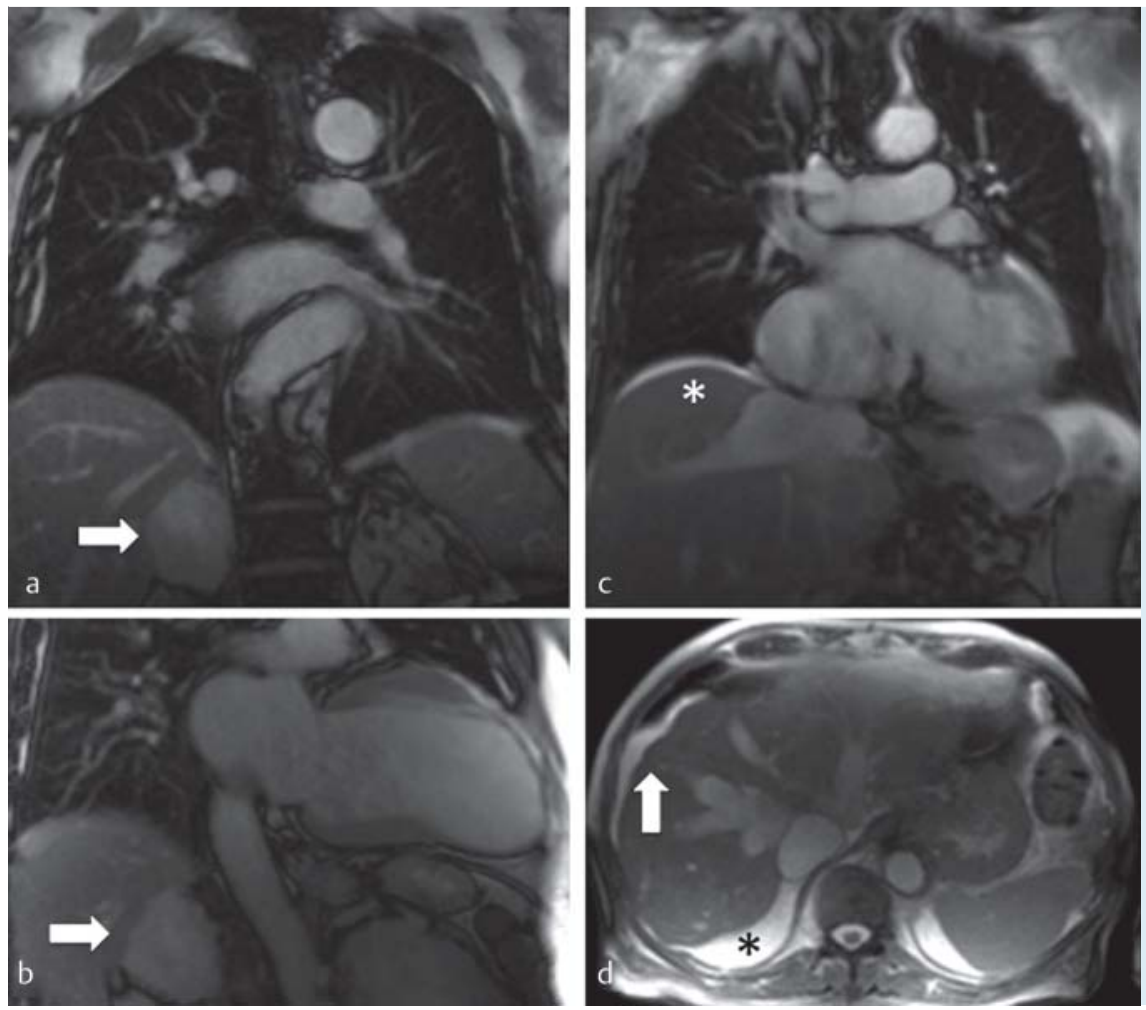

Fig. 4 The figure a shows huge adrenal gland metastases (white arrows) on the right side in the coronary survey sequence with a hyperintese signal and in a cardiac examination sequence $\mathbf{b}$ also with hyperintense signal (white arrows). Figure $\mathbf{c}$ shows hyperintense perihepatic fluid (ascites) in a case of liver cirrhosis in a coronary survey sequence and figure $\mathbf{d}$ shows the liver cirrhosis with perihepatic and perisplenic hyperintense fluid (ascites) (white and black star) and an inhomogeneous wavy liver contour (white arrow) in the axial SSFP sequence. The liver veins are also enlarged.

Abb. 4 Die Abbildung a zeigt eine große Nebennierenmetastase (weiße Pfeile) rechts in der koronaren Survey Sequenz mit hyperintensem Signalmuster und in einer koronaren kardialen Untersuchungssequenz ebenfalls mit hyperintensem Signalmuster $\mathbf{b}$. Die Abbildung c zeigt in der koronaren Survey Sequenz einen hyperintensens perihepatischen Flüssigkeitssaum (Aszites) (weißer Stern) bei einer Leberzirrhose. Die Lebervenen sind aufgeweitet. Die Abbildung d zeigt eine inhomogene wellige Leberoberfläche (weißer Pfeil) bei aufgeweiteten Lebervenen sowie perihepatischer und perilienaler Flüssigkeit (hyperintenser Flüssigkeitssaum) (weißer und schwarzer Stern) in einem Fall von Leberzirrhose in der axialen SSFP Sequenz. 
Table 4 PSEF according to summarized age groups.

Tab. 4 Zusammenfassung potentiell signifikanter extrakardialer Befunde in unterschiedliche Altersgruppen.

\begin{tabular}{|c|c|c|}
\hline & total (n) & percent $(\%)$ \\
\hline $20-29$ & 3 & 13 \\
\hline $30-39$ & 2 & 8.7 \\
\hline $40-49$ & 3 & 13 \\
\hline $50-59$ & 5 & 21.74 \\
\hline $60-69$ & 3 & 13 \\
\hline $70-79$ & 3 & 13 \\
\hline patients over 80 years & 4 & 17.4 \\
\hline patients under 40 years & 5 & 21.74 \\
\hline patients over 40 years & 18 & 78.26 \\
\hline patients over 50 years & 15 & 65.21 \\
\hline
\end{tabular}

and didn't show a benefit in the detection of PSEF. Actually with the sequences tailored to imaging of the heart and with the survey sequences, we were able to detect all of the 25 PSEF.

One pathologic finding was not visible in the additional SSFP chest sequence. The adrenal gland metastases were only delineated by the survey sequences and were not known previously. Therefore, all pathologic findings were detectable by reading the survey images.

PSEF were preferentially detected among older age groups with $65 \%$ of the PSEF detected in the age group older than 50 years. In a further study by Atalay et al., the most PSEF were detected in the patient group older than 60 years (85.6\%) [2].

In general, radiologists usually don't like reading survey images since these sequences with a large field of view are less appealing due to lower resolution and optimization for the delineation of prominent anatomical landmarks. Survey sequences only contain several slices in all three dimensions and do not cover the imaged region without a gap. In this context the larger field of view of the survey sequences compared to the additional axial SSFP chest sequence surely contributed to our result with better detection of additional findings. Otherwise, in our group of patients for example no smaller lung lesions or masses were detected and it remains unanswered if an additional axial SSFP chest sequence might be preferential in the detection of such lesions due to the smaller gap.

In the survey sequences as well as in the additional SSFP chest sequence, the diagnosis of PSEF is based on MRI morphologic characteristics without contrast agent injection. In this setting tailored imaging protocols, which contain multiple sequences with different weighting, are not available. Consequently, in some cases further and adequate characterization of the detected lesions upon CMRI is not possible. Scheduling further imaging sessions for patients or triaging them to different imaging modalities such as CT or PET-CT (positron emission tomography CT) might be necessary or required. For example, when uncertain liver lesions are detected, dynamic T1 sequences are needed to exclude hyper-vascularization in the case of questions regarding hepatocellular carcinomas.

Furthermore, when additional findings in cross-sectional imaging methods are described and additional and optimized imaging sessions in accordance with the respective research question are required, additional personnel costs and equipment costs are generated by the diagnosis of uncertain lesions. If the result is the detection of a previously unknown PSEF, early treatment might increase the success of the therapy and also effectively save costs.
However, if the second examination reveals an insignificant finding or is still inconclusive, the follow-up costs might be increased without any benefit.

\section{Conclusion}

The results of the current study demonstrate that an axial SSFP chest sequence in the CMRI setting covering the chest from the lung apex to the diaphragm without a gap, optimized for the visualization of the heart and the mediastinum, did not show a benefit in detecting additional findings. In our group of patients all PSEF were visible on the survey images. In times of cost-effectiveness and time pressure, an additional axial SSFP chest sequence might not be necessary especially when high quality survey sequences are generated.

We conclude that the survey images in CMRI patients should be assessed for additional findings.

\section{References}

1 Achenbach S, Barkhausen J, Beer $M$ et al. Konsensusempfehlung der DRG, DGK, DGPK zum Einsatz der Herzbildgebung mit Computertomografie und Magnetresonanztomografie. Fortsch Röntgenstr 2012; 184: $345-368$

2 Atalay MK, Prince EA, Pearson CA et al. The prevalence and clinical significance of noncardiac findings on cardiac MRI. Am J Roentgenol Am J Roentgenol 2011; 196: W387-W393

3 Ginnerup Pedersen B, Rosenkilde M, Christiansen TE et al. Extracolonic findings at computed tomography colonography are a challenge. Gut 2003; 52: $1744-1747$

4 Hara $A K$, Johnson CD, MacCarty RL et al. Incidental extracolonic findings at CT colonography. Radiology 2000; 215: 353 - 357

5 Hellstrom M, Svensson MH, Lasson A. Extracolonic and incidental findings on CT colonography (virtual colonoscopy). Am J Roentgenol Am J Roentgenol 2004; 182: 631-638

6 Dewey M, Schnapauff D, Teige F et al. Non-cardiac findings on coronary computed tomography and magnetic resonance imaging. Eur Radiol 2007; 17: 2038 - 2043

7 Haller S, Kaiser C, Buser P et al. Coronary artery imaging with contrastenhanced MDCT: extracardiac findings. Am J Roentgenol Am J Roentgenol 2006; 187: 105-110

8 Horton KM, Post WS, Blumenthal RS et al. Prevalence of significant noncardiac findings on electron-beam computed tomography coronary artery calcium screening examinations. Circulation 2002; 106: 532 -534

9 Hunold P, Schmermund A, Seibel RM et al. Prevalence and clinical significance of accidental findings in electron-beam tomographic scans for coronary artery calcification. Eur Heart J 2001; 22: 1748-1758

10 Mueller J, Jeudy J, Poston $R$ et al. Cardiac CT angiography after coronary bypass surgery: prevalence of incidental findings. Am J Roentgenol Am J Roentgenol 2007; 189: 414-419

11 Onuma Y, Tanabe K, Nakazawa G et al. Noncardiac findings in cardiac imaging with multidetector computed tomography. J Am Coll Cardiol 2006; 48: $402-406$

12 Schragin JG, Weissfeld JL, Edmundowicz D et al. Non-cardiac findings on coronary electron beam computed tomography scanning. J Thorac Imaging 2004; 19: $82-86$

13 Lee SY, Landis MS, Ross IG et al. Extraspinal findings at lumbar spine CT examination: Prevalence and clinical importance. Radiology 2012; 263: 502-509

14 Chan PG, Smith MP, Hauser TH et al. Noncardiac pathology on clinical cardiac magnetic resonance imaging. JACC Cardiovasc Imaging 2009; 2: $980-986$

15 McKenna DA, Laxpati M, Colletti PM. The prevalence of incidental findings at cardiac MRI. Open Cardiovasc Med J 2008; 2: $20-25$

16 Wyttenbach R, Médioni N, Santini P et al. Extracardiac findings detected by cardiac magnetic resonance imaging. Eur Radiol 2012; 22: 1295 1302 